\title{
Biological Removal of Ammonia from Municipal Landfill Leachate (Kozodrza, Poland) at Limited Oxygen Access and Presence of Kaldnes Media
}

\author{
Lukasz Jurczyk $^{* *}$, Justyna Koc-Jurczyk ${ }^{1}$ \\ 1 University of Rzeszow, Faculty of Biology and Agriculture, Department of Biological Basis of Agriculture and \\ Environmental Education, 1b Cwiklinskiej St., 35-601 Rzeszow, Poland \\ * Corresponding author's e-mail: jjurczyk@ur.edu.pl
}

\begin{abstract}
The effect of filling the sequential batch reactor (SBR) with Kaldnes biomass carrier media on the effectiveness of landfill leachate treatment was examined. The experiment was carried out under limited access to oxygen $\left(0.5-1.0 \mathrm{mg} \cdot \mathrm{L}^{-1}\right)$. The raw leachate was characterized with the COD concentration at the level of 7758 $\mathrm{mg} \cdot \mathrm{L}^{-1}, \mathrm{BOD}_{5}-904 \mathrm{mg} \cdot \mathrm{L}^{-1}$, and $\mathrm{NH}_{4}^{+}-980 \mathrm{mg} \cdot \mathrm{L}^{-1}$. The nitrogen loading rate (NLR) was low and amounted to $0.3 \mathrm{~kg} \cdot \mathrm{m}^{-3} \cdot \mathrm{d}^{-1}$. The fill fraction had no effect on the concentration of contaminants in effluents, but turned out to be significant as far as the ammonia nitrogen loss rate was concerned. During the first six hours of SBR operation, the reaction rate increased from $0.64 \mathrm{mg} \cdot \mathrm{L}^{-1} \cdot \mathrm{h}^{-1}$ to $6.85 \mathrm{mg} \cdot \mathrm{L}^{-1} \cdot \mathrm{h}^{-1}$ with increasing fill fraction. In the remaining time $(7-23 \mathrm{~h})$ in the case of the reactor operating only with suspended activated sludge, and the one with $10 \%$ of filtration media, the reaction rate was comparable, i.e. $27.24 \mathrm{mg} \cdot \mathrm{L}^{-1} \cdot \mathrm{h}^{-1}$ and $27.02 \mathrm{mg} \cdot \mathrm{L}^{-1} \cdot \mathrm{h}^{-1}$, respectively. Increasing the fill fraction to $20 \%$ resulted in a decrease of the reaction rate to $18.28 \mathrm{mg} \cdot \mathrm{L}^{-1} \cdot \mathrm{h}^{-1}$.
\end{abstract}

Keywords: landfill leachate, SBR, Kaldnes, nitrogen removal

\section{INTRODUCTION}

Landfill leachates constitute specific wastewater generated on municipal landfills and characterized with a high degree of variability, both in terms of volume and chemical composition. This poses significant difficulties in developing highly efficient treatment methods. The physiochemical parameters of landfills can vary within very wide ranges, which depends, in particular, on the landfill age, methods of operating, and the degree of waste fragmentation [Third et al. 2001, Jurczyk, Koc-Jurczyk 2014, Jurczyk Koc-Jurczyk, 2017]. Moreover, the processes occurring inside the landfill prism also have a certain effect, related to the degree of organic matter decomposition, the efficiency of biogas release, or the bed settling process [El-Fadel et al. 1997]. Landfill leachates are characterized by a high content of organic substances, resistant to biological decomposition (low $\mathrm{BOD}_{5} / \mathrm{COD}$ ratio), as well as high concen- tration of ammonia nitrogen (low N/COD ratio) [Kurniawan et al. 2006, van Hulle et al. 2010, Yusof et al. 2010]. In SBR, cyclic variations of nitrogen and organics concentrations accompanied by changes of hydrodynamic conditions (stirring, aeration, and decantation) stimulate the development of microorganisms resistant to variable environmental conditions. They also contribute to the stabilization of the process and achieving better treatment results compared to those typical for continuous flow systems [Kulikowska 2007].

One of the methods used to retain biomass in reactors and create anaerobic-aerobic conditions consists in filling them with biomass carriers. There are different commercially available carriers, such as Kaldnes (polyethylene media), Liapor (ceramic media), and Linpor (plastic media with high porosity), or polyurethane (PU) foam cubes [Kurniawan et al. 2006, Valdivia et al. 2007, Khan et al. 2012, Koc-Jurczyk Jurczyk 2017]. Lim et al. [2011] report that suspended 
biomass plays an important role in oxidation of ammonia nitrogen, as the biomass colonizing the carrier's inner space is used as a source of carbon in the denitrification process. Biomass immobilization also contributes to the retention of slower developing nitrifying bacteria in the reactor. In the case of wastewater treatment carried out in reactors with biomass carriers, the amount of the latter is an important factor. Larger surface area of the carriers allows to retain more biomass in the reactor [Wang et al. 2005].

In order to improve the nitrogen removal efficiency, processes such as nitritation-denitritation [Yang, Yang 2011] or simultaneous nitrificationdenitrification (SND) [Park et al. 2001] have been developed. In the nitrification-denitrification process, oxidation of ammonia nitrogen to nitrite occurs followed by its reduction to gaseous nitrogen. In comparison with the conventional processes employed for removal of nitrogen with the use of biological processes, the nitritation-denitritation process allows to reduce aeration by $25 \%$ and the required carbon $40 \%$. In the SND process, nitritation and denitritation occur at the same time in the same reactor, under identical conditions of the technological process. Therefore, SND is an alternative nitrogen removal technology in view of the process simplification and the possibility to use an internal carbon source such as, e.g. active sludge [Guo et al. 2013, Wang et al. 2013].

In this study, two different volumetric fractions of Kaldnes plastic rings were tested as the carrier for biomass under the conditions of limited oxygen access. In each sequential reactor, the microflora occurred both as the activated sludge suspended in whole free volume of the reactor and, partly, in the form of biological film settled on the surface of carriers. The biomass carriers create favorable conditions for an intensified growth of microorganisms inside the reactor due to well-developed active surface area, but also due to reduction of sludge swelling or washing out [Munch et al. 1996]. Microbial population forms a multilayer structure on the surface of a carrier and as a result, they show a much lower susceptibility to unfavorable environmental and technological conditions [Pal et al. 2012, Jurczyk, Koc-Jurczyk 2017].

The objective of the study was to evaluate the efficiency of organic substances and nitrogen removal from landfill leachate, depending on the total volume of carriers in an SBR. The experiment was carried out at low DO concentration and rela- tively high temperature, in order to the maximize nitrogen removal from leachate. Additionally, a kinetic analysis of process was performed.

\section{MATERIALS AND METHODS}

\section{Leachates}

The leachate used in the study originated from a landfill located in Kozodrza (South-eastern Poland). The landfill has operated for over twenty years and currently has a status of a regional installation for municipal landfill disposal, collecting approximately $400 \mathrm{Mg} \cdot \mathrm{d}^{-1}$ of waste "other than inert and hazardous". The composition of the leachate and analytical methods are listed in Table 1. The leachate was sampled once, in autumn, from the retention reservoir, to 10 -L plastic containers, then immediatley transported to the laboratory of waste management, and stored at temperature $4^{\circ} \mathrm{C}$ in the darkness, for further analysis.

\section{Operational conditions}

The research was carried out in three sequential batch reactors (SBR1-3) equipped with Kaldnes filtration media, which had a diameter of $11 \mathrm{~mm}$ and height of $7 \mathrm{~mm}$, and the specific surface area $\geq 845 \mathrm{~m}^{2} \cdot \mathrm{m}^{-3}$. SBR1 was operated as control reactor, filled only with suspended activated sludge, whilst SBR2 and 3 were filled with Kaldness filtration media in bulk volume of 10 and $20 \%$ respectively. The reactors were operated in a $24 \mathrm{~h}$ working cycle described in Figure 1.

The reactors were eqipped with fine-bubble aeration system and the dissolved oxygen (DO) concentration was maintained at the level of $0.5-1.0 \mathrm{mg} \cdot \mathrm{L}^{-1}$, and the hydraulic retention time (HRT) was set at $3 \mathrm{~d}$, and temperature at $35^{\circ} \mathrm{C}$. Each portion of the leachate was kept for $24 \mathrm{~h}$ at room temperature to warm up before introduction to the reactor. All of the reactors were inoculated with activated sludge taken from $2^{\text {nd }}$ stage of nitrification chamber of the Municipal Wastewater

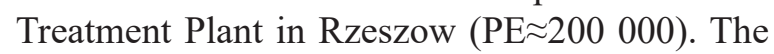
concentration of organic biomass in all reactors at the beginning of the experiment was equal to 2.3 $\mathrm{g} \cdot \mathrm{L}^{-1}$ and the nitrogen loading rate (NLR) was as low as $0.3 \mathrm{~kg} \cdot \mathrm{m}^{-3} \cdot \mathrm{d}^{-1}$. The experiment continued for 110 days. 


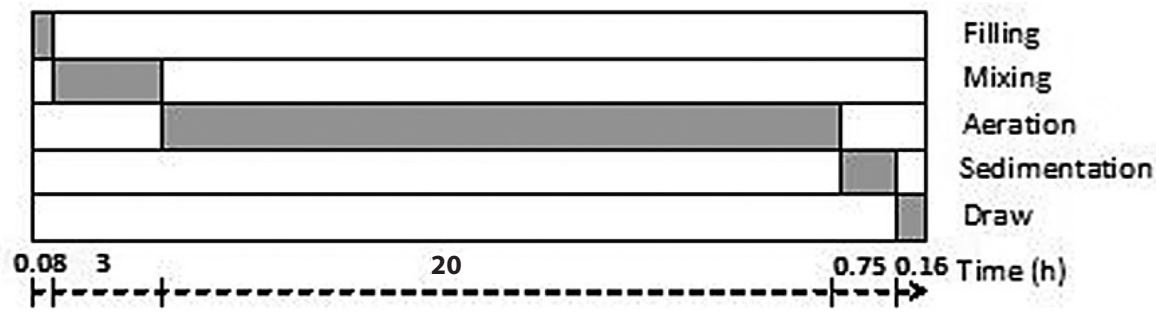

Figure 1. Characteristics of the SBRs operational cycle

\section{Analytical methods}

In both raw leachate and effluents after biological treatment, the concentrations of organic substances expressed as $\mathrm{COD}$ and $\mathrm{BOD}_{5}$, concentrations of mineral forms of nitrogen, and $\mathrm{pH}$ value were determined according to the methodology presented in Table 1.

The temperature and DO in the SBR were detected using online instruments (Elmetron).

\section{Calculations of reaction kinetics}

It was assumed that the reaction rate $r_{\mathrm{N}}$ (mg L-1 $\mathrm{h}^{-1}$ ) occurred according to the zero-order reaction (Eq. 1):

$$
r_{N}=\frac{d C_{N}}{d t}= \pm k_{0}
$$

where $C_{N}$ is the ammonium nitrogen concentration $\left(\mathrm{mg} \mathrm{L}^{-1}\right)$ after a specified time $t(\mathrm{~h})$. The constant rate of reaction $k_{0}\left(\mathrm{mg} \mathrm{L}^{-1}\right.$ $\mathrm{h}^{-1}$ ) was determined on the basis of experimental results and $C_{0}$ - the ammonium nitrogen concentration $\left(\mathrm{mg} \mathrm{L}^{-1}\right)$ at the start of SBR operation, from the following equation (Eq. 2):

$$
C_{N}=C_{0} \pm k_{0} \cdot t
$$

The rate of ammonium nitrogen removal $\left(r_{0}\right)$ expressed in activated sludge units ( $m g \mathrm{mg}_{\text {v.s.s. }}{ }^{-1} \mathrm{~h}^{-1}$ ) has been calculated from the following formula (Eq. 3):

$$
r_{0}=\frac{d C_{N}}{d t}=\frac{ \pm k_{0}}{C_{\text {v.s.s. }}}
$$

where $C_{v . s . s}$ is the concentration of suspended organic compounds $\left(\mathrm{mg}_{\mathrm{vs.S.}} \mathrm{L}^{-1}\right)$.

\section{Statistical analysis}

The differences between the measured concentrations of mineral forms of nitrogen, including: ammonium, nitrates and nitrites, in the effluents from biological reactors after the stablisation phase (arbitrarily determined from the course of curves) were first tested by nonparametric Kruskal-Wallis $\mathrm{H}$ statistics, and post-hoc by Dunn's test for each pair (1-2, $2-3,1-3)$ of reactors (Statistica 10).

\section{RESULTS AND DISCUSSION}

\section{Organics removal}

The concentration of organic substances in a sample of raw leachate, expressed as COD, was

Table 1. Physiochemical parameters of the leachate

\begin{tabular}{|c|c|l|}
\hline Parameter & Value & \multicolumn{1}{|c|}{ Method } \\
\hline $\mathrm{COD}\left[\mathrm{mg} \mathrm{L}^{-1}\right]$ & $7758 \pm 120$ & PN-ISO 6060:2006 Colorimetric method \\
\hline $\mathrm{BOD}_{5}\left[\mathrm{mg} \mathrm{L}^{-1}\right]$ & $904 \pm 65$ & DIN EN 1899-1/EN 1899-2 Respirometric method \\
\hline $\mathrm{NH}_{4}^{+}\left[\mathrm{mg} \mathrm{L}^{-1}\right]$ & $980 \pm 98$ & PN-ISO 5664:2002 Colorimetric method \\
\hline $\mathrm{NO}_{2} \cdot\left[\mathrm{mg} \mathrm{L}^{-1}\right]$ & $0.1 \pm 0.02$ & PN-ISO26777:1999 Spectrophotometric method \\
\hline $\mathrm{NO}_{3}^{-}\left[\mathrm{mg} \mathrm{L}^{-1}\right]$ & $0.15 \pm 0.1$ & PN-82/C-04576/08 Spectrophotometric method \\
\hline $\mathrm{C}_{\mathrm{t} . \text {.s. }}\left[\mathrm{g} \mathrm{L}^{-1}\right]$ & $7.589 \pm 0.569$ & Total suspended solids at 103-105 ${ }^{\circ} \mathrm{C}$ \\
\hline $\mathrm{C}_{\mathrm{v} . \text {..s. }}\left[\mathrm{g} \mathrm{L}^{-1}\right]$ & $1.895 \pm 0.325$ & Fixed and volatile solids ignited at $550^{\circ} \mathrm{C}$ \\
\hline $\mathrm{pH}$ & $8.5 \pm 0.5$ & PN/90/C-04540.01 Potentiometric method \\
\hline $\mathrm{BOD} / \mathrm{COD}$ & $0.11 \pm 0.5$ & - \\
\hline $\mathrm{N} / \mathrm{COD}$ & $0.13 \pm 0.8$ & - \\
\hline
\end{tabular}


$7758 \mathrm{mg} \mathrm{L}^{-1}$, whereas $\mathrm{BOD}_{5}-904 \mathrm{mg} \mathrm{L}^{-1}\left(\mathrm{BOD}_{5} /\right.$ COD ratio 0.12 ). The efficiency of organics removal from leachates throughout the course of biological treatment, and COD concentrations in effluent from SBRs are shown in Figure 2.

The efficiency of COD removal exceeded $40 \%$, regardless of the volume of fill inside the reactors. In the effluent from the reactor operating only with suspended activated sludge, an average COD concentration was $4439.16 \mathrm{mg} \mathrm{L}^{-1}$, compared to $4600.41 \mathrm{mg} \mathrm{L}^{-1}$ and $4247.23 \mathrm{mg} \mathrm{L}^{-1}$ observed in the reactors filled with $10 \%$ and $20 \%$ of biomass carriers bulk volume, respectively. In the case of organic carbon compounds, the outflows have stabilized after 26 days of experiment. Statistically significant differences in COD concentration were observed between all the reactors (Figure 3a, Table 2).

Kulikowska [2012] has applied a similar variant of technological procedure for the treatment of landfill leachates. COD removal efficiency was much higher (75\%) than the one obtained in the present study, $\mathrm{BOD}_{5} / \mathrm{COD}$ ratio in raw leachate was higher as well (0.6). Akgul et al. [2013] have treated leachates characterized by average $\mathrm{BOD}_{5} /$ COD ratio at the level of 0.62 in a MBR. The efficiency of COD removal ranged from $40 \%$ to $85 \%$, while $\mathrm{BOD}_{5}$ exceeded $90 \%$. The observed COD removal efficiency was lower than the reported in the above-mentioned literature, as a result of low concentration of easily degradable organic substances in the examined leachate $\left(\mathrm{BOD}_{5} /\right.$ $\mathrm{COD}=0.11$ ). According to the results published by Jakopović et al. [2008] and Tsilogeorgis et al. [2008], in the case of leachate from old landfills, COD removal efficiency was $23 \%$ and $40-60 \%$, respectively. Additionally, the temperature at which the treatment process is conducted has an effect not only on COD removal efficiency but also on the process stabilization rate. Guo et al. [2013] inform that with increasing temperature, the time necessary to reach the maximum COD removal rate shortens. At $5^{\circ} \mathrm{C}$ and $10^{\circ} \mathrm{C}, 4 \mathrm{~h}$ of aeration is required, and at $20^{\circ} \mathrm{C}$ and $30^{\circ} \mathrm{C}-3 \mathrm{~h}$ of aeration. The highest COD removal efficiency observed in the study was obtained after 3 hours of aeration (Figure 4).

\section{NITROGEN REMOVAL}

The leachates used in this study were characterized with the total nitrogen concentration at the level of $1068.6 \mathrm{mg} \cdot \mathrm{L}^{-1}$, in which the ammonia nitrogen contributed to almost $92 \%$. The raw leachate was free from both nitrite and nitrate nitrogen. In effluent leachates, regardless of the adopted technological variant, ammonia nitrogen dominated and the concentration of nitrite and nitrate did not exceed the values of $0.3 \mathrm{mg} \cdot \mathrm{L}^{-1}$ and $1 \mathrm{mg} \cdot \mathrm{L}^{-1}$, respectively (Figure 5 ). The performed research indicates that along with increasing fill fraction, the efficiency of ammonia removal from leachates decreased from $78 \%$ to $67 \%$. In the case of mineral forms of nitrogen, the outflows have stabilized after 64 days of experiment. Statistically significant differences in $\mathrm{N}-\mathrm{NO}_{2}$ concentration were observed between all the reactors (Figure $3 b$ ), whilst there were no significant differences in $\mathrm{N}_{-} \mathrm{NH}_{4}^{+}$between SBR1 and 2 (Figure 3c), nor in $\mathrm{N}-\mathrm{NO}_{3}$ between SBR1 and 3 (Figure 3d).

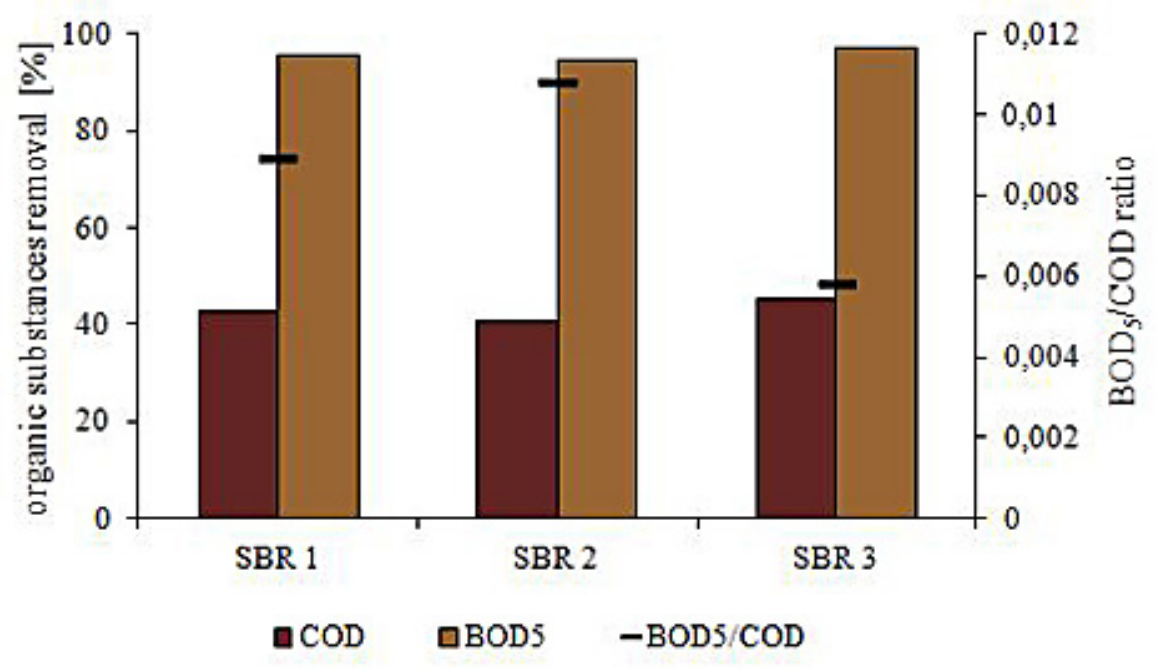

Figure 2. Organics removal efficiency and $\mathrm{BOD}_{5} / \mathrm{COD}$ ratio in leachates after the treatment 

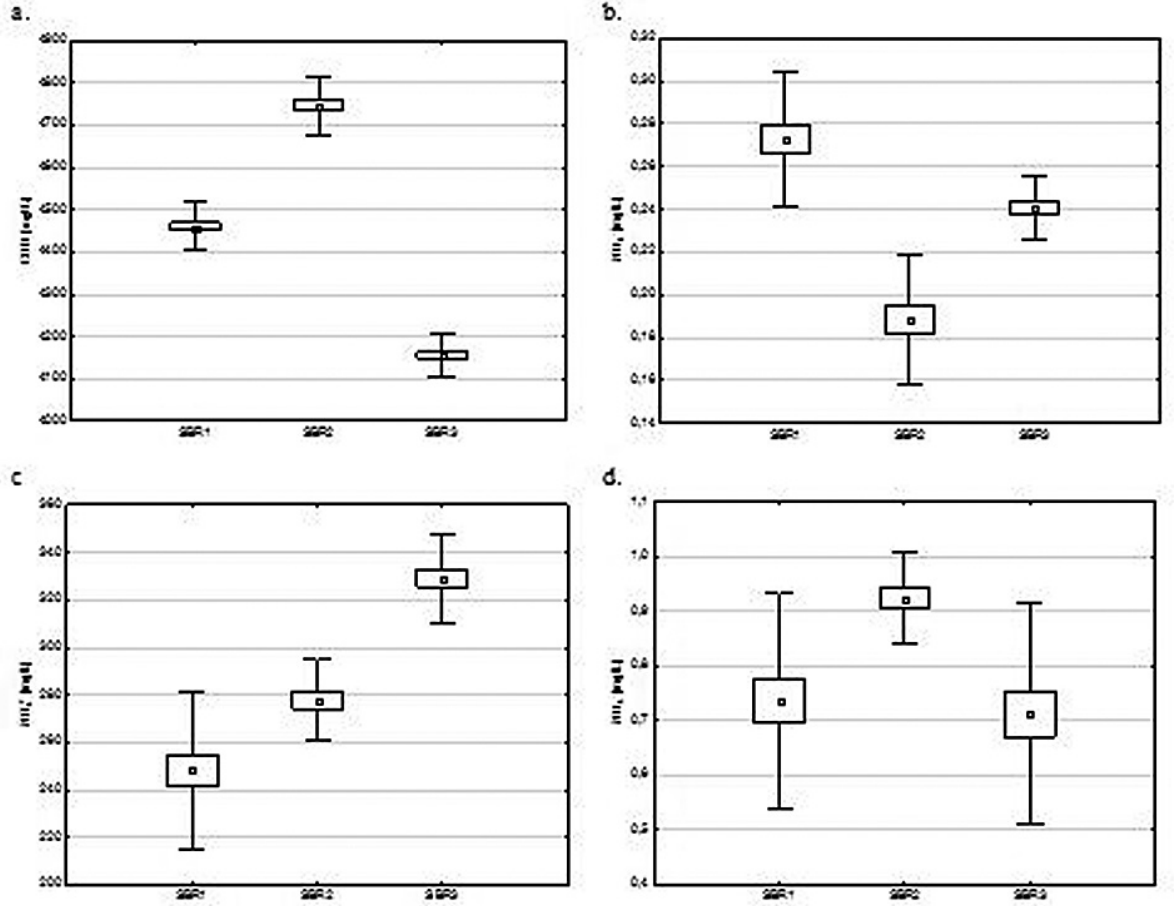

Figure 3. Statistical analysis of differences in the concentrations of organic compounds and mineral nitrogen forms between outflows from SBRs, [mean values $(\square), \pm \mathrm{SE}(\square)$ and $\pm \mathrm{SD}(\perp)$ ]

Table 2. Dunn's test values for multiple comparisons. Statistically significant differences $(p \leq 0.05)$ marked with an asterisk

\begin{tabular}{|c|c|c|c|}
\hline \multicolumn{2}{|c|}{ Specification } & SBR2 & SBR3 \\
\hline \multirow{2}{*}{ COD } & SBR1 & $\begin{array}{l}4.948824 \\
0.000002^{*}\end{array}$ & $\begin{array}{l}5.042525 \\
0.000001 *\end{array}$ \\
\hline & SBR2 & & $\begin{array}{c}9,991349 \\
0^{*}\end{array}$ \\
\hline \multirow{2}{*}{$\mathrm{NO}_{2}$} & SBR1 & $\begin{array}{l}6.751885 \\
0.000000^{*}\end{array}$ & $\begin{array}{l}2.558682 \\
0.031521^{*}\end{array}$ \\
\hline & SBR2 & & $\begin{array}{l}4,193203 \\
0,000083^{*}\end{array}$ \\
\hline \multirow{2}{*}{$\mathrm{NH}_{4}^{+}$} & SBR1 & $\begin{array}{l}2.141430 \\
0.096718\end{array}$ & $\begin{array}{l}6.920854 \\
0.000000^{*}\end{array}$ \\
\hline & SBR2 & & $\begin{array}{l}4.779424 \\
0.000005^{*}\end{array}$ \\
\hline \multirow{2}{*}{$\mathrm{NO}_{3}$} & SBR1 & $\begin{array}{l}3.427668 \\
0.001826^{*}\end{array}$ & $\begin{array}{l}0.324146 \\
1.000000\end{array}$ \\
\hline & SBR2 & & $\begin{array}{c}3.751813 \\
0.000527^{*}\end{array}$ \\
\hline
\end{tabular}

Quite large losses of ammonium nitrogen, considered as a difference between the concentration value at the end and beginning of the operating cycle, were observed in the course of treatment. The ammonium nitrogen losses have decreased in the reactor with larger fraction of filling. In the case of the reactor operating with $20 \%$ of media, the ammonia nitrogen loss was on the level of $378 \mathrm{mg} \cdot \mathrm{L}^{-}$ , compared to $464.8 \mathrm{mg} \cdot \mathrm{L}^{-1}$ for $10 \%$ of media and $484.4 \mathrm{mg} \cdot \mathrm{L}^{-1}$ for activated sludge only. Kulikowska
[2007] treated the leachate from a municipal waste landfill, located in the rural area of north-eastern Poland, in SBRs that worked at room temperature, with HRT of 3 days. During the stirring phase, ammonia nitrogen loss was relatively small, while during the aeration, the unbalanced ammonia nitrogen losses amounted to $25.5 \mathrm{mg} \cdot \mathrm{L}^{-1}$. Zhang et al. [2014] reported that, in a highly nitrogen-loaded MBR, the achieved the ammonia nitrogen loss of $190 \mathrm{mg} \cdot \mathrm{L}^{-1}$, compared to $79.5 \mathrm{mg} \cdot \mathrm{L}^{-1}$ in a lowloaded MBR, and the ammonia nitrogen removal efficiency under such conditions could reach $99 \%$ and $95 \%$, respectively. In the present experiment, DO concentration ranged between $0.5-1 \mathrm{mg} \cdot \mathrm{L}^{-1}$, compared to $0.15 \mathrm{mg} \cdot \mathrm{L}^{-1}$ in the above-mentioned studies of Zhang et al. [2014], whereas the result published by Kulikowska [2007] were achieved in $2-3 \mathrm{mg} \cdot \mathrm{L}^{-1}$, with similar other technological parameters. This may suggest that unbalanced ammonia nitrogen losses are related to DO concentration. Elimination of ammonia nitrogen in the systems based on the activated sludge maintained under anaerobic-aerobic conditions can be linked with the ability of Nitrosomonas genus bacteria, to produce nitrogen oxides and molecular nitrogen [Stüven et al. 1992, de Graaf et al. 1997, Park et al. 2001, Yao et al. 2013]. According to Park et al. [2001], during the process of ammonia nitrogen removal from municipal wastewater, $\mathrm{N}_{2} \mathrm{O}$ was gen- 


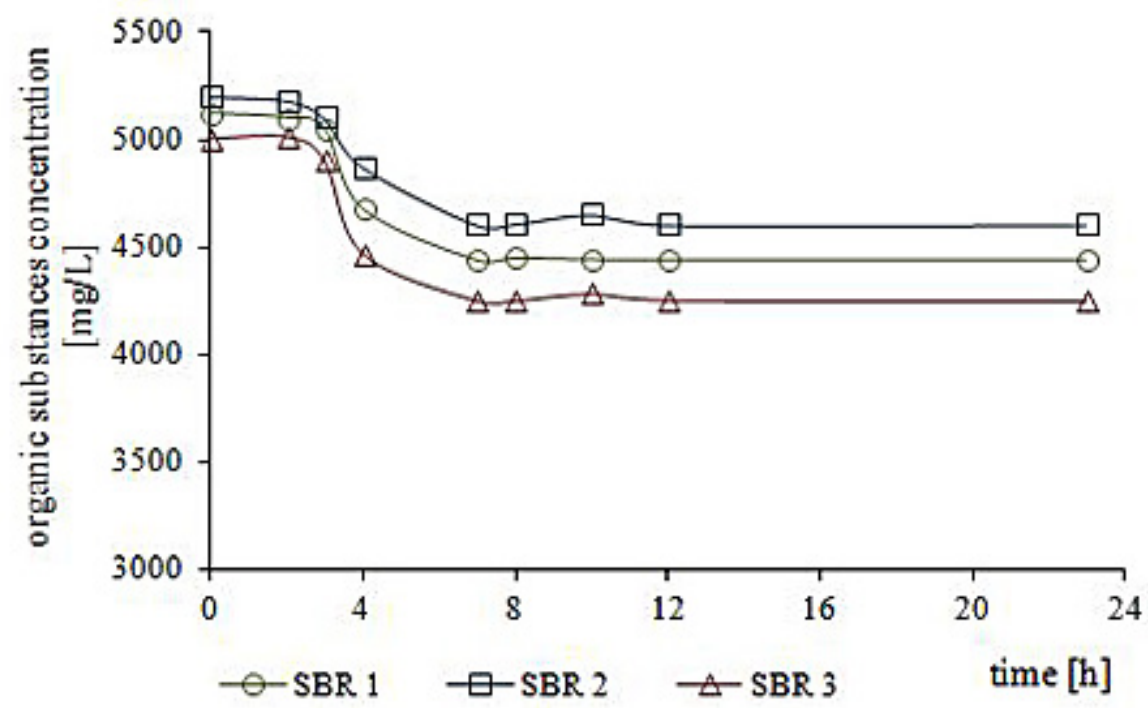

Figure 4. Organic compounds concentration (COD) profiles throughout a SBR operation cycle

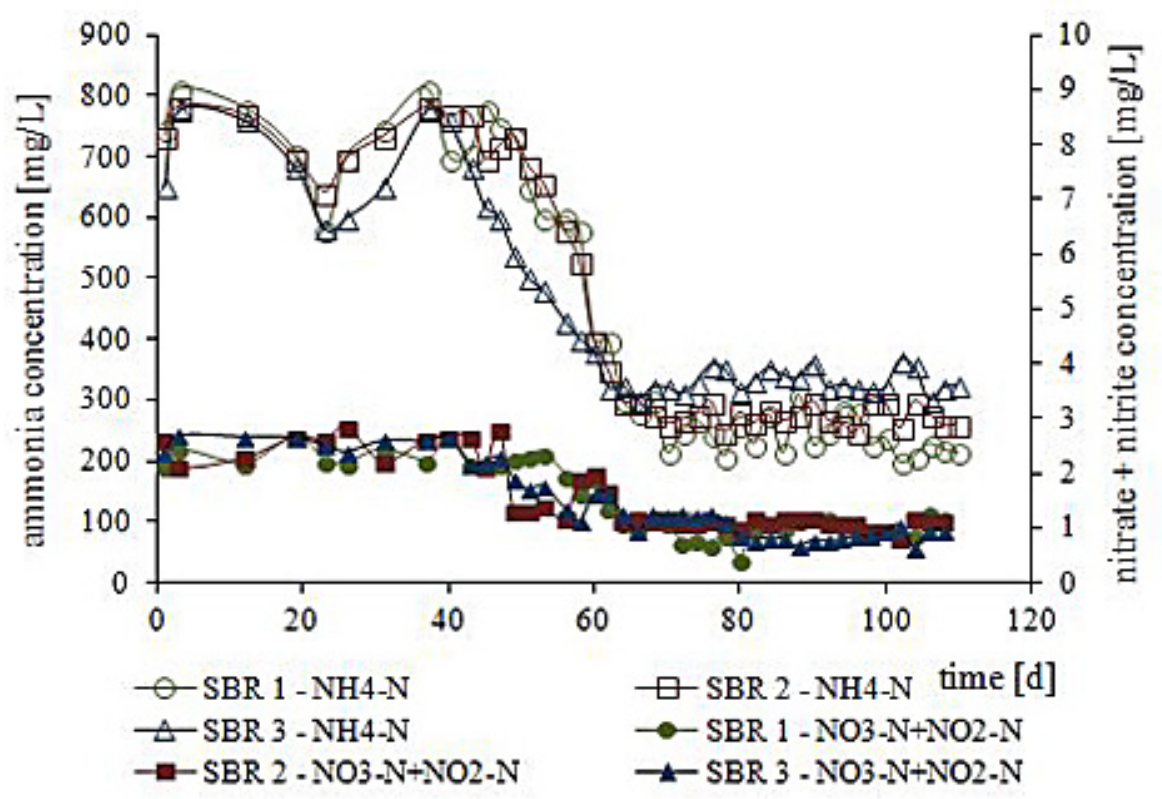

Figure 5. The ammonium nitrogen removal efficiency and concentrations of mineral forms of nitrogen in effluents from SBRs equipped with different bulk volumes of biomass carrier

erated mainly in the beginning of aeration phase, when DO concentration did not exceed $1 \mathrm{mg} / \mathrm{L}$. Yao et al. [2013] informed that plantomycete-like Anammox bacteria bioactivity could be enhanced by increasing the concentration of $\mathrm{N}_{2} \mathrm{H}_{4}$, the compound which seems to be one of the main intermediate products of the reaction, according to the possible metabolic pathways.

It has been found that ammonia nitrogen removal from leachates can proceed according to the 0 -order reaction. It passes through the two stages (Figure 6), the $1^{\text {st }}$ stage lasted 6 hours and comprised $3 \mathrm{~h}$ of stirring and $3 \mathrm{~h}$ of aeration, the $2^{\text {nd }}$ starts after the sixth hour of the SBR operating cycle. As it follows from the data presented in Table 3, during $1^{\text {st }}$ stage, the reaction rate per unit of reactor volume increased along with the volumetric fraction of biomass carrier, from 0.64 $\mathrm{mg} \cdot \mathrm{L}^{-1} \cdot \mathrm{h}^{-1}$ in the reactor operated only with suspended sludge, up to $6.85 \mathrm{mg} \cdot \mathrm{L}^{-1} \cdot \mathrm{h}^{-1}$ in the reactor containing $20 \%$ fill by volume. During the $2^{\text {nd }}$ stage, the proportion of filling had no effect on the reaction rate. In the case of reactors operated with suspended sludge and $10 \%$ of media, the reaction 


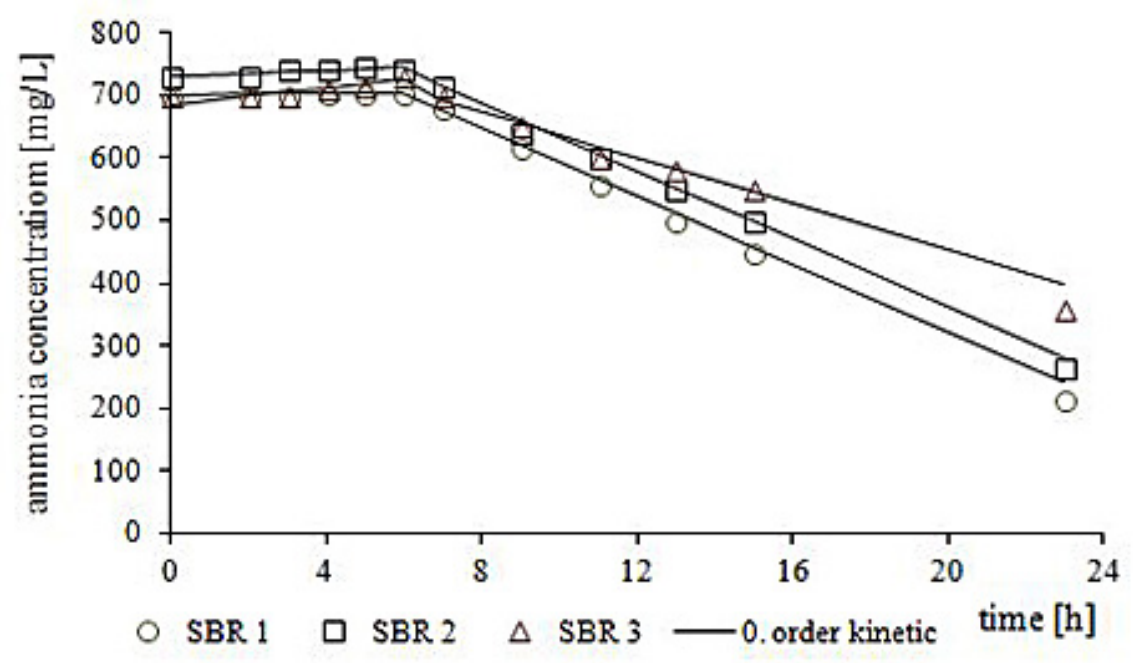

Figure 6. Ammonia nitrogen concentration profiles in the course of anaerobic and aerobic phase in an SBR

Table 3. Rate of ammonia nitrogen removal described by means of the 0 -order reaction

\begin{tabular}{|c|c|c|c|c|c|c|}
\hline \multirow{2}{*}{ Time [h] } & \multicolumn{2}{|c|}{ SBR 1} & \multicolumn{2}{|c|}{ SBR 2} & \multicolumn{2}{|c|}{ SBR 3} \\
\hline & $0-6$ & $7-24$ & $0-6$ & $7-24$ & $0-6$ & $7-24$ \\
\hline$r_{N}\left[\mathrm{mg} \mathrm{L}^{-1} \mathrm{~h}^{-1}\right]$ & 0.64 & -27.24 & 2.53 & -27.02 & 6.85 & -18.28 \\
\hline $\mathrm{r}_{0}\left[\mathrm{mg} \mathrm{mg}_{\mathrm{v} \text { s.s. }}{ }^{-1} \mathrm{~h}^{-1}\right]$ & 0.24 & 10.52 & 0.93 & 9.48 & 2.49 & 6.66 \\
\hline$C_{\text {v.s.s. }}\left[g_{\text {v.s.s. }} L^{-1}\right]$ & \multicolumn{2}{|c|}{2.588} & \multicolumn{2}{|c|}{2.707} & \multicolumn{2}{|c|}{2.743} \\
\hline $\mathrm{R}^{2}$ & 0.48 & 0.99 & 0.4 & 0.99 & 0.59 & 0.99 \\
\hline
\end{tabular}

rate was comparable, $27.24 \mathrm{mg} \cdot \mathrm{L}^{-1} \cdot \mathrm{h}^{-1}$ and 27.02 $\mathrm{mg} \cdot \mathrm{L}^{-1} \cdot \mathrm{h}^{-1}$ respectively. Increasing the fraction of media to $20 \%$ resulted in a decrease of the reaction rate to $18.28 \mathrm{mg} \cdot \mathrm{L}^{-1} \cdot \mathrm{h}^{-1}$.

A higher percentage of movable filling inside the reactor results in a mechanical rubbing of its elements against each other, which continually wipes out the surface of biofilm and makes it more compact and thinner [Morgenroth, Wildere 2000, Wang et al. 2005]. The resulting thinner biofilm can shows higher biological activity, which contributes to higher efficiency of contamination removal, per biomass unit [Peyton 1996, Vieira, Melo, 1999]. Analyzing the ammonium nitrogen loss rate per unit of organic biomass $\left(r_{0}\right)$ it has been found that the application of $20 \%$ bulk volume of media resulted in a 10-fold increase of the reaction rate during the $1^{\text {st }}$ stage, similarly as the reaction rate per unit of reactor volume $\left(r_{\mathrm{N}}\right)$. In the $2^{\text {nd }}$ stage of ammonium nitrogen removal, a 1.5 -fold decrease of reaction rate was determined for both the volume unit and organic biomass. Similar results were obtained by Lim et al. [2011] who observed a decrease of the reaction rate $\left(r_{N}\right)$ with increasing SBR fill fraction from $20^{\times} 10^{2} \mathrm{mg} \cdot \mathrm{L}^{-1} \cdot \mathrm{min}^{-1}$ in the reactor filled in $20 \%$ to $15.7^{\times} 10^{2} \mathrm{mg} \cdot \mathrm{L}^{-1} \cdot \mathrm{min}^{-1}$ in the reactor filled in $40 \%$. Such a decrease of the reaction rate could be a result of smaller external surface area of the media. This may suggest that the main role in the process of ammonium removal from leachates is played by the suspended biomass, rather than the biomass settled on the media. However, an increase in the reaction ratio in $1^{\text {st }}$ stage $(6 \mathrm{~h})$ following the increase of SBR filling fraction could be caused by the biomass settled on carriers being used as a carbon source in the denitrification process and heterotrophic nitrification [de Graaf et al. 1997, Guo et al. 2013].

In the present research, application of the fill had no effect on the total organic biomass content in SBRs. The initial organic biomass concentration in each of the reactors was $2.3 \mathrm{~g} \cdot \mathrm{L}^{-1}$. In the SBR running on suspended sludge only, there were better conditions for the development of active sludge. Application of $10 \%$ and $20 \%$ of media resulted in the transfer of part of the biomass on it. The organic sludge growth rate was $12.5 \%, 17.7 \%$, and $19.3 \%$ in the SBRs with suspended sludge, $10 \%$ and $20 \%$ of media, respectively. It follows from the above that the presence of Kaldnes media has a stimulating effect on the growth of organic component of the active sludge. The average mass of total suspended solid was highest in effluent from SBR1 $\left(777.5 \mathrm{mg} \cdot \mathrm{L}^{-1}\right)$ 


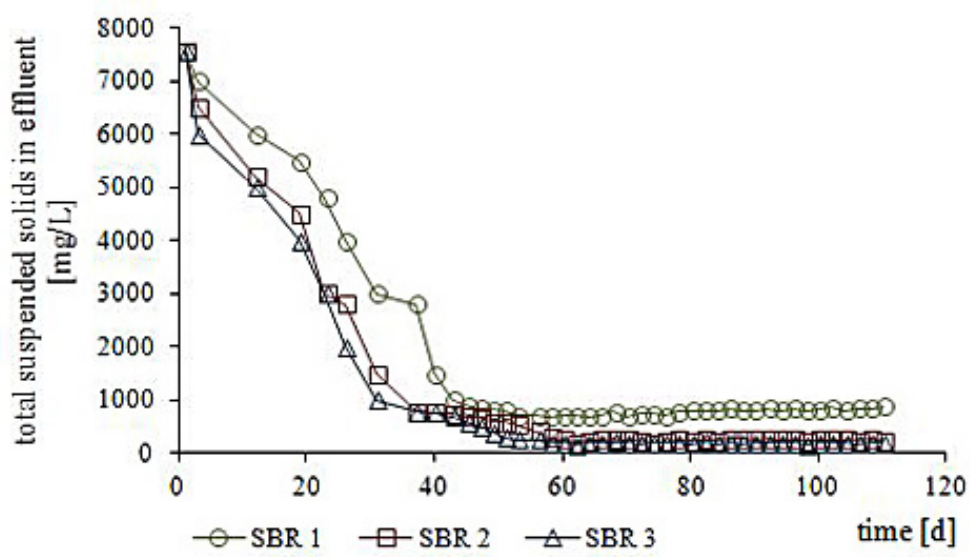

Figure 7. The average mass of total suspended solid in effluent from SBRs

after its stabilisation (53 d), whilst much lower in SBR2 $\left(265 \mathrm{mg} \cdot \mathrm{L}^{-1}\right)$ and SBR3 $\left(195 \mathrm{mg} \cdot \mathrm{L}^{-1}\right)$ where biomass carriers prevent the runoff of the activated sludge (Figure 7).

Additionally, the presence of fill inside the SBR limits the washing out of the active sludge together with the effluent. In the results reported by Kulikowska [2007], the ammonium nitrogen loss rate in the SBR operating cycle occurred according to 0 -order formula, similarly as in the present study. The literature data shows that for HRT between $0.5-1 \mathrm{~d}$ and DO concentration $0.3-0.7 \mathrm{mg} \cdot \mathrm{L}^{-1}$, ammonia nitrogen removal efficiency could reach $76-78 \%$, regardless of temperature $\left(21-34^{\circ} \mathrm{C}\right)$. On the other hand, the rate of ammonia nitrogen removal is two times lower at the temperature $21^{\circ} \mathrm{C}\left(20.8 \mathrm{mg} \cdot \mathrm{L}^{-1} \cdot \mathrm{h}^{-1}\right)$ than at $34^{\circ} \mathrm{C}\left(45.8 \mathrm{mg} \cdot \mathrm{L}^{-1} \cdot \mathrm{h}^{-1}\right)$ [Ahn 2006]. Guo et al. [2013] report that the temperature increase from $10^{\circ} \mathrm{C}$ to $32.5^{\circ} \mathrm{C}$ resulted in a 1.36 -fold increase of the ammonium removal rate during the SBR treatment of landfill leachate, whereas according to Wett [2006] and van Hulle et al. [2010], at $25^{\circ} \mathrm{C}$ and DO concentration $0.3-1 \mathrm{mg} \mathrm{L}^{-1}$, ammonium nitrogen removal efficiency was even $84-90 \%$, and its loss rate was reaches $16.6-27 \mathrm{mg} \cdot \mathrm{L}^{-1} \cdot \mathrm{h}^{-1}$. Temperature of $35^{\circ} \mathrm{C}$ and DO concentration in the range $0.5-1.0 \mathrm{mg} \cdot \mathrm{L}^{-1}$ was adopted in this study. The obtained rate of ammonia nitrogen removal from leachates was $18.28-27.24 \mathrm{mg} \cdot \mathrm{L}^{-1} \cdot \mathrm{h}^{-1}$ and was close to the values reported in the literature.

\section{CONCLUSIONS}

It has been found that the efficiency of COD removal from municipal waste landfill leachate was higher than $40 \%$, and $\mathrm{BOD}_{5}$, despite it was in small proportion, it exceeded $90 \%$, regardless of amount of filling in SBR. Ammonium nitrogen dominated both in raw leachate and the effluents form the ractors. With increasing of fill fraction, the efficiency of ammonia removal decreased. Ammonium nitrogen removing process occurred in two stages. In the $1^{\text {st }}$ stage, the reaction rate increased with increasing volume of biomass carrier, in the $2^{\text {nd }}$ stage, the fill had no effect of the reaction rate. In the case of reactors operating with the fill fraction $10 \%$ and without it, the observed reaction rates were comparable. An increase of the fill fraction to $20 \%$ resulted in a decrease of the reaction rate.

\section{REFERENCES}

1. Ahn Y-H. 2006. Sustainable nitrogen elimination biotechnologies: a review. Process Biochem., 41, 1709-1721.

2. Akgul D., Aktan C.K., Yapsakli K., Mertoglu B. 2013. Treatment of landfill leachate using UASBMBR-SHARON-Anammox configuration. Biodegradation, 24, 399-412.

3. de Graaf A.A.V., de Bruijn P., Robertson L.A., Jetten M.S.M., Kuenen J.G. 1997. Metabolic pathway of anaerobic ammonium oxidation on the basis of $\mathrm{I} 5 \mathrm{~N}$ studies in a fluidized bed reactor. Microbiology, 143, 2415-2421.

4. El-Fadel M., Findikakis A.N., Leckie J.O. 1997. Environmental impacts of solid waste landfilling. J. Environ. Manage., 50, 1-25.

5. Guo J., Zhang L., Chen W., Mac F., Liu H., Tian Y. 2013. The regulation and control strategies of a sequencing batch reactor for simultaneous nitrification and denitrification at different temperatures. Bioresource Technol., 133, 59-67. 
6. Jakopovié H.K., Matošié M., Muftié M., Čurlin M., Mijatovié I. 2008. Treatment of landfill leachate by ozonation, ultrafiltration, nanofiltration and membrane bioreactor. Fresenius Environmental Bulletin., 17, 687-695.

7. Jurczyk Ł., Koc-Jurczyk J. 2014. Changes in the approach to waste disposal and generation of the leachate. Archives of Waste Management and Environmental Protection 16, 31-40.

8. Jurczyk Ł., Koc-Jurczyk J. 2017. Quantitative dynamics of ammonia-oxidizers during biological stabilization of municipal landfill leachate pretreated by Fenton's reagent at neutral $\mathrm{pH}$. Waste Manage., 63, 310-326.

9. Khan S.J., Rehman Z.U., Visvanathan C., Jegatheesan V. 2012. Influence of biofilm carriers on membrane fouling propensity in moving biofilm membrane bioreactor. Bioresource Technol., 113, 161-164.

10. Koc-Jurczyk J., Jurczyk L. 2017. Biological Treatment of Landfill Leachate at Elevated Temperature in the Presence of Polyurethane Foam of Various Porosity. Clean - Soil, Air, Water, 45(3).

11. Kulikowska D. 2007. Treatment of municipal landfill leachate using activated sludge system and adsorption on activated carbon. Czasopismo Techniczne, 2, 145-155.

12. Kulikowska D. 2012. Nitrogen removal from landfill leachate via the nitrite rote. Braz. J. Chem. Eng., 29, 211-219.

13. Kurniawan T.A., Lo W.H., Chan G.Y.S. 2006. Physico-chemical treatments for removal of recalcitrant contaminants from landfill leachate. J. Hazard. Mater., B129, 80-100.

14. Lim J.W., Seng C.E., Lim P.E., Ng S.L., Sujari A.N.A. 2011. Nitrogen removal in moving bed sequencing batch reactor using polyurethane foam cubes of various sizes as carrier materials. Bioresource Technol., 102, 9876-9883.

15. Maslon A., Tomaszek J.A. 2015. A study on the use of the BioBall $\AA$ as a biofilm carrier in a sequencing batch reactor. Bioresource Technol., 196:577-585.

16. Morgenroth E., Wildere P.A. 2000. Influence of detachment mechanisms on competition in biofilms. Water Res., 34:417-426.

17. Munch E.V., Lant P., Keller J. 1996. Simultaneous nitrification and denitrification in bench-scale sequencing batch reactors. Water Res., 30, 277-284.

18. Pal L., Kraigher B., Brajer-Humar B., Levstek M., Mandic-Mulec I. 2012. Total bacterial and ammonia-oxidizer community structure in moving bed biofilm reactors treating municipal wastewater and inorganic synthetic wastewater. Bioresource Technol., 110, 135-143.

19. Park K.Y., Lee J.W., Inamori Y., Mizuochi M., Ahn K.H. 2001. Effects of fill modes on $\mathrm{N} 2 \mathrm{O}$ emission from the SBR treating domestic wastewater. Water Sci. Technol., 43, 147-150.
20. Peyton B.M. 1996. Effects of shear stress and substrate loading rate on Pseudomonas aeruginosa biofilm thickness and density. Water Res., 30, 29-36.

21. Stüven R., Vollmer M., Bock E. 1992. The impact of organic matter on nitric oxide formation by Nitrosomonas europea. Arch. Microbiol., 158, 439-443.

22. Third K.A., Sliekers A.O., Kuenen J.G., Jetten M.S. 2001. The CANON system (Completely Autotrophic Nitrogen-removal Over Nitrite) under ammonium limitation: interaction and competition between three groups of bacteria. Syst. Appl. Microbiol., 24, 588-596.

23. Tsilogeorgis J., Zouboulis A., Samaras P., Zamboulis D. 2008. Application of a membrane sequencing batch reactor for landfill leachate treatment. Desalination, 221, 483-493.

24. Valdivia A., Gonzalez-Martinez S., Wilderer P.A. 2007. Biological nitrogen removal with three different SBBR. Water Sci. Technol., 55, 245-254.

25. van Hulle S.W.H., Vandeweyer H.J.P., Meesschaert B.D., Vanrolleghem P.A., Dejans P., Dumoulin A. 2010. Engineering aspects and practical application of autotrophic nitrogen removal from nitrogen rich streams. Chem. Eng. J., 162, 1-20.

26. Vieira M.J., Melo L.F. 1999. Intrinsic kinetics of biofilms formed under turbulent flow and low substrate concentrations. Bioprocess Eng., 20, 369-375.

27. Wang K., Wang S., Zhu R., Miao L., Peng Y. 2013. Advanced nitrogen removal from landfill leachate without addition of external carbon using a novel system coupling ASBR and modified SBR. Bioresource Technol., 134, 212-218.

28. Wang R.C., Wen X.H., Qian Y. 2005. Influence of carrier concentration on the performance and microbial characteristics of a suspended carrier biofilm reactor. Process Biochem., 40, 2992-3001.

29. Wett B. 2006. Solved upscaling problems for implementing deammonification of rejection water. Water Sci. Technol., 53, 121-128.

30. Yang S., Yang F.L. 2011. Nitrogen removal via short-cut simultaneous nitrification and denitrification in an intermittently-aerated moving bed membrane bioreactor. J. Hazard. Mater., 195, 318-323.

31. Yao Z.B., Cai Q., Zhang D.J., Xiao P.Y., Lu P. 2013. The enhancement of completely autotrophic nitrogen removal over nitrite (CANON) by $\mathrm{N} 2 \mathrm{H} 4$ addition. Bioresource Technol., 146, 591-596.

32. Yusof N., Hassan M.A., Phang L.Y., Tabatabaei M., Othman M.R., Mori M., Wakisaka M., Sakai K., Shirai Y. 2010. Nitrification of ammonium-rich sanitary landfill leachate. Waste Manage., 30, 100-109.

33. Zhang X., Li D., Liang Y., Zeng H., He Y., Zhang Y., Zhang J. 2014. Performance and microbial community of completely autotrophic nitrogen removal over nitrite (CANON) process in two membrane bioreactors (MBR) fed with different substrate levels. Bioresource Technol., 152, 185-191. 